\title{
Study of Bacteriological and Parasitological Management Quality of Water in the Villages of Senegal
}

\author{
Louis Régis Dossou-Yovo ${ }^{*}$, Colette Gomis-Mansaly², Isabelle Mady-Goma Dirat ${ }^{3}$, \\ Fatoumata Sarr Diene ${ }^{4}$, Alioune Badara Ly ${ }^{4}$, Ronan Jambou ${ }^{1}$ \\ ${ }^{1}$ Immunology Clinic and Parasitic Laboratory, Institut Pasteur, Dakar, Senegal \\ ${ }^{2}$ Food Security and Environmental Hygiene laboratory, Institut Pasteur, Dakar, Senegal \\ ${ }^{3}$ Laboratory of Research of Animal Biology and Ecology, ENS, Marien N'Gouabi University, Brazzaville, Congo \\ ${ }^{4}$ Epidemiology Service, Institut Pasteur, Dakar, Senegal \\ Email: *doyorel2@gmail.com
}

How to cite this paper: Dossou-Yovo, L.R., Gomis-Mansaly, C., Mady-Goma Dirat, I., Sarr Diene, F., Ly, A.B. and Jambou, R. (2019) Study of Bacteriological and Parasitological Management Quality of Water in the Villages of Senegal. Journal of Biosciences and Medicines, 7, 205-217. https://doi.org/10.4236/jbm.2019.712016

Received: November 12, 2019 Accepted: December 17, 2019

Published: December 20, 2019

Copyright $\odot 2019$ by author(s) and Scientific Research Publishing Inc. This work is licensed under the Creative Commons Attribution International License (CC BY 4.0).

http://creativecommons.org/licenses/by/4.0/

\begin{abstract}
A survey on the parasitological and bacteriological management was conducted in two villages in southeastern Senegal. The objective of this study was to evaluate the water management modalities in the two villages with ethnic differences and possibly detect factors that could cause waterborne diseases. A questionnaire on water management methods was submitted to one hundred one women drawn in the villages of Dielmo and Ndiop. Samples of well water and water stored in canaries were subjected to both parasitological and bacteriological analysis. In both villages, there was a difference in water management with respect to household configuration (monogamous, polygamous). The containers used for the drawing and storage of water were the same in their two villages. No helminth eggs were found in the drinking water, but bacterial germs, especially faecal coliforms (an indicator of human contamination) and Enterocoques (an indicator of animal contamination). These waters do not comply with WHO standards. So it is important to disinfect them before consumption although no cases of gastroenteritis have been reported.
\end{abstract}

\section{Keywords}

Water Management, Contamination, Helminth, Bacteria, Dielmo, Ndiop, Senegal

\section{Introduction}

The microbiological quality of drinking water is a major concern around the 
world because of its impact on public health [1]. It is established today that most infectious diseases that are prevalent throughout the world and particularly in developing countries are waterborne [2] [3] [4]. This is through the contamination of drinking water by excreta (feces) of human and animal origin. According to the World Health Organization, more than 80 infectious diseases can be transmitted by water [5]. Among the pathogens responsible for these diseases we can mention bacteria (Salmonella, Shigella), viruses (hepatitis A and hepatitis E) and parasites (Entamoeba histolytica, Giardia lamblia, Crytosporidium vum ...) [2] [6] [7]. For WHO, in 2017, 71\% of the world's population (5.3 billion people) used a safe drinking water service; $90 \%$ of the world's population (6.8 billion people) had access to at least one basic service. 785 million people did not even have a basic water supply and 144 million of them had to use surface water. Worldwide, 2 billion people use faecally contaminated water points [8]. Diarrhea remains the second leading cause of death, especially among children under 5 years of age [9] [10] [11] [12]. The main factors favoring these diseases are the lack of hygiene, drinking water and sanitation, but also poor management of water resources, which favors the proliferation of bacterial germs. Many village associations, governmental and non-governmental organizations are involved in water sanitation projects. Large drilling programs are being conducted in rural areas while water distribution systems are improving in urban areas. Outside crisis contexts, the situation should improve gradually. Yet all these efforts are in vain if the family management of the water is deficient either because of elementary means of storage or by ignorance of the basics of hygiene. In Senegal, drinking water supply programs have been in existence for more than half a century and the infrastructure is quite well developed. Yet waterborne diseases persist as elsewhere in the ranking of causes of morbidity. Few studies have been conducted in Senegal on the safety of drinking water in rural areas; those conducted in the outlying districts of Dakar reveal that households do not have adequate sanitation facilities: solid and liquid domestic waste is discharged directly onto the ground and latrines are defective, causing coliform pollution of the water table fecal matter [13]. In the present work, we propose to study the management of drinking water in two villages in dry zones with ethnic and hydrographic differences, to detect if possible the factors that can lead to waterborne diseases (diarrhea) and to serve as a basis for supporting a health strategy.

\section{Materials and Methods}

\subsection{Study Area}

The water quality management took place in two villages: Dielmo and Ndiop. Dielmo $\left(13^{\circ} 45^{\prime} \mathrm{N}, 16^{\circ} 25^{\prime} \mathrm{W}\right)$ and Ndiop $\left(13^{\circ} 14^{\prime} \mathrm{N}, 16^{\circ} 23^{\prime} \mathrm{W}\right)$ are located at $280 \mathrm{~km}$ in the Southeast of Dakar, approximately to $15 \mathrm{~km}$ to the North of Gambia and are distant between them of $5 \mathrm{~km}$ [14] [15]. The rainy season spreads from June to October. The yearly middle precipitations knew of big fluctuations these last 
thirty years passing $1000 \mathrm{~mm}$ before 1972 to Dielmo to $583 \mathrm{mms}$ in 1992 and to Ndiop of $603 \mathrm{mms}$ in 1993 to $521 \mathrm{~mm}$ in 1996. Dielmo counts 250 inhabitants Serer in majority (78\%) and Mandingue (13\%); Ndiop counts 350 inhabitants to Wolof majority and Peul. Dielmo distinguishes itself by the presence of a river and an intense permanent transmission of the malaria whereas in Ndiop, the transmission is moderate and seasonal [14].

\subsection{People Selection}

Concessions that are part of the survey protocol on the malaria put in place since ten years were selected in two villages. Predefined questionnaires relative to modes of water management, translated in Serer (Dielmo) and in Wolof (Ndiop) were submitted to the different families. These questionnaires, built in French, have been translated in Serer or Wolof the two villages. They have been tested then on a group of women of every village to assess the relevance; every woman was considered to represent a family. 101 families were drawn according to the method of totals accumulated of populations, in order to conduct the study for an acceptable duration.

\subsection{Water Sample}

We have taken Water samples were collected in all 12 wells of both villages with sterile buckets attached to sterile rope. For parasitological analysis, 5 liters of water were collected in the sterile jerrican and $500 \mathrm{ml}$ of water were collected in the sterile glass bottles with screw cap for the bacteriological analysis. In addition, a sample of water was collected and stored $500 \mathrm{ml}$ of water stored in the canaries with selected with sterile big spoon.

\subsection{Parasitological Analysis of Water}

For helminth eggs numeration in wells water, used the protocol of the EPA were (Environment Protection Agency), procedures 388, 389, 390, 391, 392, 393 Helminth eggs (11-25-91). We modified the quantity of water to analyze, we took 5 liters instead of 20 liters. The validation method used for helminth eggs numeration in water has been made by suspending stools (whose quantity of eggs has been determined by the method of Kato) [16]. In $20 \mathrm{ml}$ of water filtered, then making dilutions of this suspension to evaluate the method sensitivity.

\subsection{Bacteriological Analysis of Water}

Samples stored at $4^{\circ} \mathrm{C}$ were routed to the institute Pastor of Dakar in the Laboratory of Food Security and Environmental Hygiene (LSAHE), where they were immediately analyzed according to protocols normalized XP T90-401 for the numbering of revivifiable microorganisms at $37^{\circ} \mathrm{C}, \mathrm{XP}$ T90-402 for the numbering of revivifiable microorganisms to $22^{\circ} \mathrm{C}$, NF T90-414 for research and the numbering of coliforms and thermotolerant, coliforms, NF T90-415 for research and the numbering of bacteria spores anaerobic sulfito-reducting and of sulfi- 
to-reducing clostridium, XP T90-416 for research and the numbering of enterocoques). Samples $(100 \mathrm{ml})$ were filtered on sterile membranes, that were placed next in the special surroundings: PCA middle (Flat Count Agar), the TTC middle (Triphenyl-Tetrazolium Chloride), the Slanetz and Bartley middle for Streptococci, the VF middle (Meat + Liver) for the sulfito-reducing anaerobic spores that was put to steams it to $44^{\circ} \mathrm{C}$ for the fecal coliform research and to $37^{\circ} \mathrm{C}$ for the total coliform research.

\subsection{Statistical Analysis}

Data were computered and transferred to Excel (socio-demographic). Then, they were transferred on Statistica ${ }^{\bowtie}$ (StatSoft France) for the statistical analyses. Frequencies (in percentage) of some parameters (different ethnic groups percentage, illiterate woman percentage, frequencies of water draw...) and averages were calculated while using the elementary descriptive figures. The comparison test has been used in certain cases to see if the observed differences were meaningful.

\section{Results and Discussion}

\subsection{Sociodemographic Features}

During this study, 101 women have been interrogated (39 at Dielmo and 62 at Ndiop). They were distributed respectively in 30 and 26 concessions averaging 1.3 women by concession to Dielmo and 2.38 women for Ndiop. The age average of these women is $47.7 \pm 0.7$ years. In the two villages, the total number of children of these women was 348 children, averaging 3.4 children by women. The child age average is identical in the two villages (11.7 \pm 0.7 years). The ethnic groups distribution of women differed according to villages (Figure 1). At Dielmo, most women are Serer or Mandingue whereas at Ndiop, women are by majority Wolof and Peul. In both villages, we meet also the Toucouleur and the Socé. Only some Bambara women were present at Dielmo.

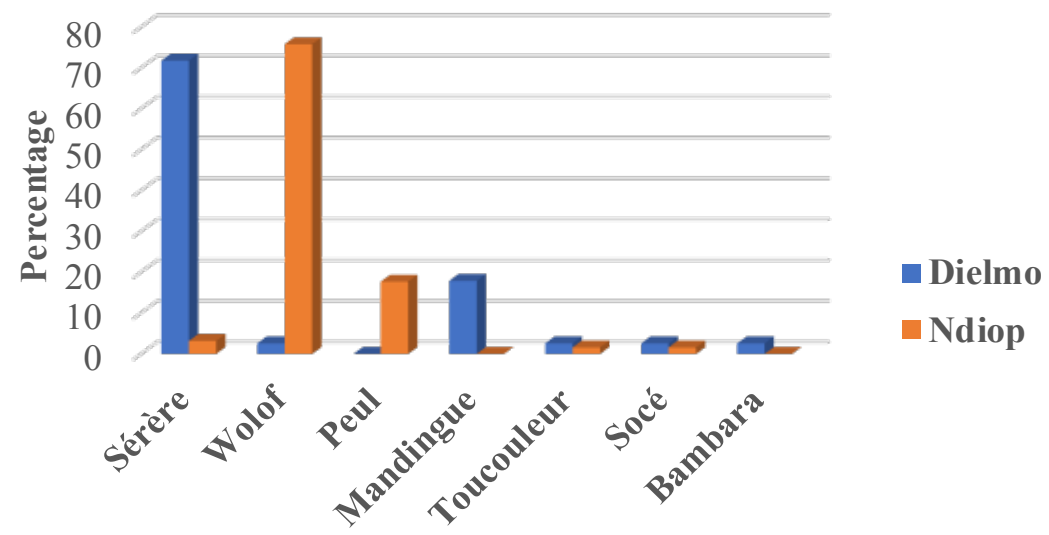

Ethnic group

Figure 1. Ethnic distribution of women. 
At Dielmo, $73.2 \%$ of women are in the monogamous homes for only $28 \%$ at Ndiop. Mandingue women (80\%) and Serer (73.3\%) local ethnic groups were the most often in the monogamous households, unlike immigrant ethnic groups (Peul and Toucouleur, 50\%; Wolof, 21.3\%); all Bambara women are in the polygamous households. The study put in evidence the different socio-demographic aspects of Dielmo and Ndiop villages. It turns out that there are two major ethnic groups, Serer at Dielmo and Wolof at Ndiop, this is consistent with the results obtained by other authors [14]. The polygamy was more frequent at Ndiop than at Dielmo. The traditions of the local majority ethnic groups seem to be a determining factor: Serer would not have a polygamous tradition unlike Wolof; this could be explained by the fact that a beef must be slaughtered during the wedding ceremony. Breeder being more numerous at Ndiop, men of this village got married more easily. In addition to their household activity, women often have an activity outside of the concession. They are either commercial, farmers or pupils. Wolof women (72.9\%), Peul (91.7\%), Toucouleur and Socé (50\%) are farmers. All commercial women are Wolof but few $2.08 \%$ of women of this ethnic group). All pupils women were Serer and represent 3.2\% of their ethnic group. At Dielmo, most families who live in the same compound have common vegetable gardens (56.4\%) and house pets (61.5\%), while at Ndiop $82.3 \%$ of families manage individually their vegetable gardens and $56.5 \%$ their livestock. It was noted that in both villages, women had at least three children on average, children are considered like a wealth in rural areas since they constitute a potential free labor force also for field work as for breeding women, as manager of the home have their domestic activity in addition, of the parallel activities (trade, agriculture especially) generating of money that allows them to contribute to the home life.

\subsection{Children Number}

The number of children by ethnic group was also variable (Figure 2). So, Serer women had on average $3.7 \pm 0.4$ children, Wolof women on average $3.4 \pm 0.3$, Peul women on average $3.3 \pm 0.6$, Mandingue women on average $3.8 \pm 1.01$, Toucouleur women on average $4.5 \pm 0.5$, Socé women on average $5.5 \pm 1.5$ and Bambara women, on average 1. It was noted that women in monogamous households have $3.8 \pm 0.4$ children on average while those of the polygamous households have $4.1 \pm 0.5$ children respectively for the first wives $3.6 \pm 0.5$ children, for the second wives, $1.7 \pm 0.6$ children for the third wives and $2 \pm 1.2$ children for the fourth wives.

\subsection{The Illiteracy Rate}

The illiteracy rate of women was high, (87.2\% at Dielmo; $96.8 \%$ at Ndiop). The other women don't pass the primary teaching level. The ethnic group also influenced this distribution because only Serer women (16.2\%) and Wolof women (4.2\%) had been to school. Among children in Dielmo, 30.8\% were illiterate compared to 62.9 in Ndiop. Primary level Children represented 57.5\% in Dielmo 


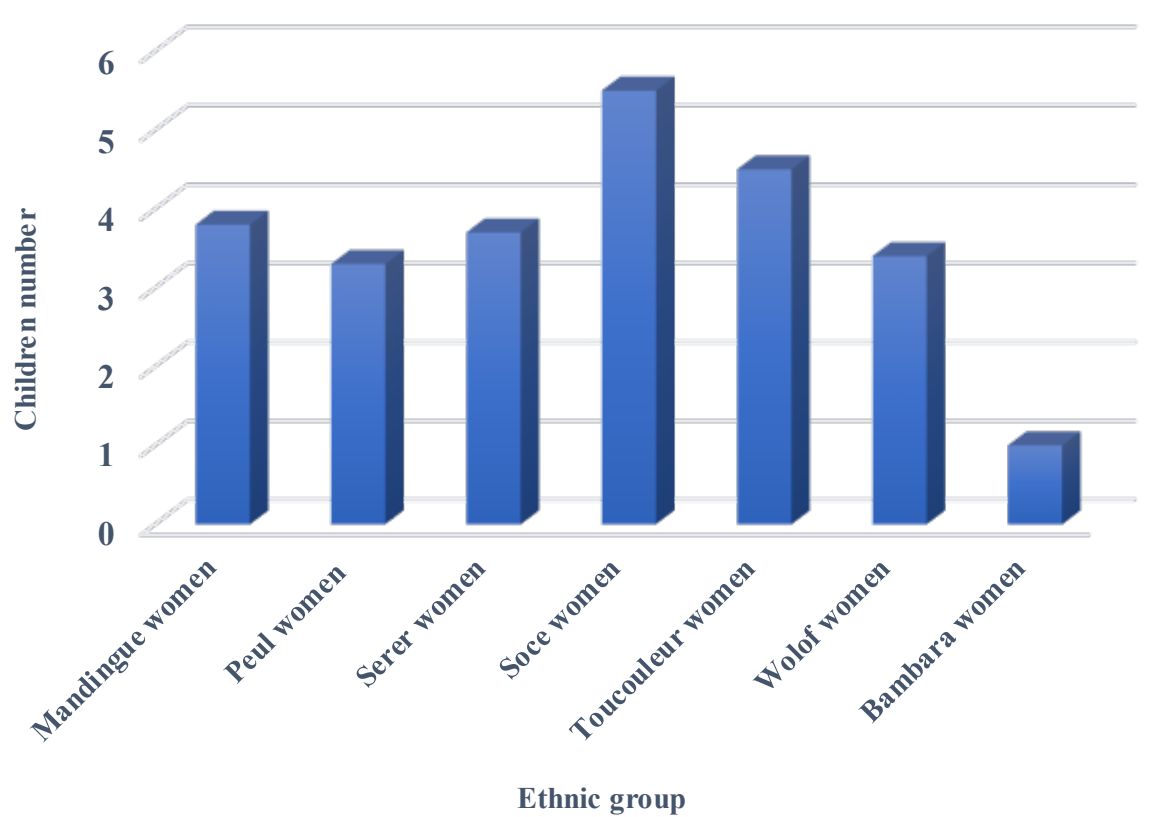

Figure 2. Distribution of children number according to women ethnic group.

against $18.7 \%$ in Ndiop, despite the existence of a school built by the project in both villages. The illiteracy rate was higher for both children and women, although there are some children and some women whose grade level doesn't exceed primary; this situation could be due to a late implantation of a primary school in the two villages. However, he also noted that some parents prefer to give religious education to their children (Koranic school) rather than a formal education ("so-called" French school). The education level of mothers has little influence on children's literacy: $52 \%$ children of illiterate women were not instructed; $42.9 \%$ children of the educated woman are illiterate. First wives had more of children in school than the following (47.4\% against $40.3 \%)$. At Dielmo and Ndiop, the majority of families has latrines (51.3\% and 92\%). At Ndiop, all families use common latrines in concessions. At Dielmo, only $38.5 \%$ of families used common latrines in concessions. Most of these families at Dielmo (60\%) and at Ndiop (92.5\%) reported that their latrines were far from the wells.

\subsection{Mode of Water Management}

Beyond the well the water and the dish contamination depends on all the chain of management of the clean "water". We interested ourselves therefore to: that draws, when and how; how water was transported; how it was stocked and in short; how the dish herself was stocked. Wells are the only source of provision in water for the two villages; Dielmo accounted nine and Ndiop three.

\subsection{Mode of Water Drawing}

The two studied villages had a very different management of water (Table 1). At Dielmo the management was mainly individual: $61.5 \%$ of families draw water individually and $71.5 \%$ stock it individually; while at Ndiop behaviors were more 
Table 1. Modes of water management in both villages.

\begin{tabular}{|c|c|c|}
\hline \multirow{2}{*}{ Water Management } & Dielmo village & Ndiop village \\
\hline & Percentage (\%) & Percentage (\%) \\
\hline Individual drawing & 61.5 & 32.3 \\
\hline Individual storage & 71.5 & 32.8 \\
\hline \multicolumn{3}{|c|}{ Transportation } \\
\hline Pan & 58.3 & 93.5 \\
\hline Pan/bucket & 38.5 & 6.5 \\
\hline Pan/jerricane & 5.1 & 0 \\
\hline Bucket & 2.6 & 0 \\
\hline \multicolumn{3}{|c|}{ Storage } \\
\hline Canary & 89.7 & 72.6 \\
\hline Pan/canary & 7.7 & 9.7 \\
\hline Canary/jerricane & 0 & 17.7 \\
\hline Canary/bucket & 2.6 & 0 \\
\hline Reserved containers to the transportation & 23.1 & 72.6 \\
\hline Reserved containers to the storage & 84.6 & 100 \\
\hline
\end{tabular}

communal (32.3\% of draw and $32.8 \%$ of storage individuals), the draw frequency also varies. At Dielmo 2 to 10 times in the morning and 1 to 5 times in the evening while at Ndiop they make it $1-3$ times the morning and once in the evening. What can translate the easier access to well. The polygamous households, the chored water concerns generally more the youngest women: $60 \%$ of the first wives, $71.4 \%$ of second wives, $83.3 \%$ of third wives and all fourth women. It was noted that in polygamous households the percentage of women involved in water fetching was higher in the second and third wives. It was noted that in the polygamous households, the percentage of women concerned by the water chore was higher in the second, third and fourth wives. This is because these women were younger and the tradition maintains a wives hierarchy in polygamous homes, they were therefore more concerned by housework than the first wife.

\subsection{Mode of Water Transport}

At Ndiop, only the open containers (pans) were used for the water transport (93.5\%). At Dielmo, in addition of pans (58.3\%), 46\% of families use jerricans and buckets to transport water (Table 2). However, in this village, containers were rather multiple use (76.9\%) unlike Ndiop (27.4\%). These containers are cleaned once per day ( $89 \%$ at Ndiop; $71.8 \%$ at Dielmo). The cleaning is summary with the hands before the drawing. The different behaviors were very bound to the ethnic group. The majority of women, whatever their ethnic group used pans for water transport, but the simultaneous use of pans and buckets was rarer among the Wolof (4.2\%) and Peul (9.1\%) than others ethnic groups: Serer (36.7\%), Mandingue (42.9\%), Toucouleur and Socé (50\%). All Socé and Bambara women used multi-purpose containers, unlike Serer (13\%) and Wolof (25\%). 
Table 2. Bacteriological quality of water.

\begin{tabular}{ccccc}
\hline & \multicolumn{2}{c}{ Dielmo village } & \multicolumn{2}{c}{ Ndiop village } \\
\cline { 2 - 5 } & $\mathrm{N}$ & $(\%)$ & $\mathrm{N}$ & $(\%)$ \\
\hline Wells water $(\mathrm{N})$ & 9 & - & 3 & - \\
Thermotolerant coliforms & 9 & 100 & 3 & 100 \\
Enterocoques & 9 & 100 & 3 & 100 \\
Spores ASR & 3 & $33.3 \%$ & 0 & 0 \\
Canaries water $\left(\mathrm{N}_{1}\right)$ & 11 & - & 19 & - \\
Thermotolerant coliforms & 11 & 100 & 16 & 84.2 \\
Enterocoques & 10 & 90.9 & 17 & 89.5 \\
Spores ASR & 0 & 0 & 0 & 0 \\
\hline
\end{tabular}

$\mathrm{N}=$ Well number, $\mathrm{N}_{1}=$ Canaries number.

However, the Bambara women cleaned their containers three times a day, others clean them once a day. Whatever the woman ranks in the household, most between them used pans for transporting water from well to the concession. The woman age, her marital statute and the type of household (mono/polygamous), statutes didn't induce significant differences in behavior across samples.

\subsection{Mode of Water Storage}

All families in Ndiop have containers reserved for storage against $84.6 \%$ of families in Dielmo. The main way of storage was canaries especially at Dielmo $(90 \%$ of families against $72.6 \%$ at Ndiop). The simultaneous use of canaries and pans was rare: $7.7 \%$ for Dielmo and $9.7 \%$ for Ndiop. At Ndiop, some families (17.7\%) also use jerricans. Containers in which water was stocked were covered with a tray or a plate. The water storage methods vary little according to the ethnic group of women. The majority of women only use these containers to stock water, the woman age doesn't influence this behavior.

\subsection{Ranging Mode of Dishes}

Habits were quite different for the two villages: At Dielmo the half of families arranged the dish on the floor and the other in a cupboard; At Ndiop, $72.6 \%$ of families arrange the dishes in height and all families take the precaution to cover the dish unlike at Dielmo. When considering the ethnicity of women, we noted that all Bambara women, Peul (81.8\%), Wolof (68.8\%), Serer women (53.3\%), Socé (50\%) and Mandingue (28.6\%) arrange their dish on a support. All Peuls women, $97.9 \%$ of Wolof, $23.3 \%$ of Serer women, $26.6 \%$ of Mandingue women, $50 \%$ of Toucouleur and Socé cover their dishes, while Bambara women didn't protect their dishes. Women having an activity outside of the house (farming, trade) took more cares of their dish while placing it in height and covering it unlike housewives who keep their dish to soil $(55.1 \%)$ without covering it $36.7 \%$ of women). The woman's school level didn't yet influence the management of the dish. 


\subsection{Medicines Use}

In Dielmo nearly $82 \%$ of women admitted to having their children dewormed (of which $38.5 \%$ recently) while in Ndiop only $56 \%$ of women did (of which $46.8 \%$ a long time ago). Products used for the deworming are mainly the Flagyl and the Vermox. Wolof used more the Flagyl and the Serer more the Vermox, other ethnic groups women used the Flagyl as well that the Vermox. The frequent use of flagyl by Wolof and Vermox by Serer could be an indicator of the prevalence of different intestinal parasitosis prevalence in the different villages where these ethnic groups are the majority. Whatever the ethnic group and the village, most women used products coming from the project station. The education plays an important role in this approach to care because all women who have been to school practice the deworming of children against $64.8 \%$ of the illiterate women. Most women admitted to having their children disinfected in the previous six months which shows the positive impact of the medical assistance structures available to the population. Whatever the instruction level or the ethnic group, women obtain in majority medicines to the project station. However, it was observed that the same proportion of educated and unqualified can mention the product name used (average 60\%).

\subsection{Parasitological Contamination of Drinking Water}

After well water analysis, no well contaminated with helminth eggs was not observed. No helminth eggs have been found in the well water of two villages, what can be explained by a strong percentage of latrine presence that decreased the anarchical defecations, no use of faecal fertilizers in agriculture decrease as well as the soils contamination [17]. These results, although related to helminth eggs were in agreement of those obtained by [18], concerning well water used for watering vegetables. These results are contrary to those obtained by [19] [20] in Nigeria, in Iran [21] and in Tunisia [22] who detected parasites in parasitic samples, mainly Protozoa. This could be explained by the fact that we used the Kato method which is specific to the search for helminth eggs while other authors used standards to search both helminth eggs and cysts of protozoa.

\subsection{Bacteriological Contamination of Drinking Water}

The wells water of two villages was contaminated by thermotolerant coliforms enterocoques and the sulfite-reducing anaerobic spores (Table 2). It is the same with the drinking water stocked in canaries of concessions. The contamination degree was appreciated according to criteria of the World Organization of Health [23]. The analysis showed a contamination of all wells in both villages by thermotolerant coliforms and enterocoques; this contamination degree is too high. The contamination by the sulfito-reducing anaerobic spores was also observed but only in 3 of the 9 wells of Dielmo. Water stocked in canaries was also contaminated, so at Dielmo, all waters of drink were contaminated by coliforms thermo tolerant whereas at Ndiop, 16 of the 19 canaries were contaminated. Enterocoques contaminate 10 canaries at Dielmo against 17 at Ndiop. The sulfi- 
to-reducing anaerobic spores were not present in the water of drink. The water analysis revealed the pollution of all wells by the bacterial agents of fecal origin, notably the fecal coliforms and enterocoques which is consistent with the results obtained at Yaoundé in Cameroon [24], at Yeumbeul in Senegal [13], in Niamey in Niger [25] and comparable to those found in Bolivia [26]; in the Ontario in Canada [27] who found that $93 \%$ and $20 \%$ respectively of wells were contaminated by the bacterial agents. More recent studies have confirmed the observations made previously, that of the contamination of drinking water (from wells, springs, boreholes, etc.) by microbial agents (total coliforms and fecal coliforms) rendering them unfit for the consumption [28] [29] [30]. The presence of these bacteria is contrary to WHO standards [23] regarding the bacteriological quality of the drinking water. These different bacteria indicate the contamination origin; thus, the fecal coliforms indicate a human contamination origin and the Enterocoques indicate an animal contamination origin. These different contaminations could be explained by the fact that the animals drink around the wells, deposit the dung on the ground or sometimes drag the containers used for the drawing and the water transport in the two villages. However, it was difficult for this study to predict whether this contamination concerns the whole aquifer or if, it was locally induced by the exploitation conditions. These bacterial germs are responsible for gastro-intestinal illnesses [27].

\section{Conclusion}

The present study was carried out from August 2001 to April 2002. We noted the predominance of two big ethnic groups: the Wolof (at Ndiop) and the Serer (at Dielmo). The structure of families is also different in the two villages, where there were more polygamous households in Ndiop than in Dielmo. The rate of illiteracy was high among the children of both villages despite the presence of a primary school. Most women dewormed their children and know the names of the products used, despite their low level of education, thanks to the presence of medical assistance. In Ndiop, the draw and the storage of water were managed in a communal way, whereas in Dielmo habits were often individualistic in relation to the high number of polygamous households in Ndiop. Frequencies of draw are more important at Dielmo. Pans and canaries are containers of choice for the draw and the storage of water in the two villages. However, the study didn't recover helminths eggs in water; on the other hand, we noted the presence of bacterial germs both in the well water and in the canaries.

\section{Acknowledgements}

Authors are grateful to Dielmo and Ndiop inhabitants for their availability.

\section{Conflicts of Interest}

The authors declare no conflicts of interest regarding the publication of this paper. 


\section{References}

[1] Amira, A.A. and Yassir, M.E. (2011) Bacteriological Quality of Drinking Water in Nyala, South Darfur, Sudan. Environmental Monitoring and Assessment, 175, 37-43. https://doi.org/10.1007/s10661-010-1491-7

[2] WHO (1993) Guidelines for Drinking Water Quality. World Health Organization, Geneva, 1-29.

[3] Reynolds, K.A., Mena, K.D. and Gerba, C.P. (2007) Risk of Water-Borne Illness via Drinking Water in the United States. Reviews of Environmental Contamination and Toxicology, 192, 117-158. https://doi.org/10.1007/978-0-387-71724-1_4

[4] Jones, A.Q., Majowicz, S.E., Edge, V.L., Thomas, M.K., Mac-Dougall, L., Fyfe, M., Atashband, S. and Kovacs, S.J. (2007) Drinking Water Consumption Patterns in British Columbia: An Investigation of Associations with Demographic Factors and Acute Gastrointestinal Illness. Science of the Total Environment, 388, 54-65. https://doi.org/10.1016/j.scitotenv.2007.08.028

[5] Ayaz, S., Khan, S., Khan, S.N., Bibi, F., Shamas, S. and Akhtar, M. (2011) Prevalence of Zoonotic Parasites in Drinking Water of Three Districts of Khyber Pakhtunkhwa Province, Pakistan. Pakistan Journal of Life and Social Sciences, 9, 67-69.

[6] Pommervilli, J. (2007) Alcamo's Laboratory Fundamentals of Microbiology. 8th Edition, Jones and Bartlett Publisher, Burlington.

[7] WHO (2002) The World Health Report. World Health Organization, Geneva.

[8] https://www.who.int/fr/news-room/fact-sheets/detail/drinking-water

[9] Kotloff, K.L., Nataro, J.P., Blackwelder, W.C., Nasrin, D., Farag, T.H., Panchalingam, S., Wu, Y., Sow, S.O., Sur, D., Breima, R.F. and Faruque, A.S. (2013) Burden and Aetiology of Diarrhoeal Disease in Infants and Young Children in Developing Countries (the Global Enteric Multicenter Study, GEMS): A Prospective, Case-Control Study. The Lancet, 382, 209-222.

https://doi.org/10.1016/S0140-6736(13)60844-2

[10] Checkley, W., White, A.C., Jaganath, D., Arrowood, M.J., Chalmers, R.M., Chen, X.M., Fayer, R., Griffiths; J.K., Guerrant, R.L., Hedstrom, L. and Huston, C.D. (2015) A Review of the Global Burden, Novel Diagnostics, Therapeutics, and Vaccine Targets for Cryptosporidium. The Lancet Infectious Diseases, 15, 85-94. https://doi.org/10.1016/S1473-3099(14)70772-8

[11] Platts-Mills, J.A., Babji, S., Bodhidatta, L., Gratz, J., Haque, R., Havt, A., McCormick, B.J., McGrath, M., Olortegui, M.P., Samie, A. and Shakoor, S. (2015) Pathogen Specific Burdens of Community Diarrhoea in Developing Countries: A Multisite Birth Cohort Study (MAL-ED). The Lancet Global Health, 3, 564-575. https://doi.org/10.1016/S2214-109X(15)00151-5

[12] Squire, S.A. and Ryan, U. (2017) Cryptosporidium and Giardia in Africa: Current and Future Challenges. Parasites Vectors, 10, 1-32.

https://doi.org/10.1186/s13071-017-2111-y

[13] Dieng, Y., Tandia, A.A., Wane, A.T., Gaye, O., Diop, E.H.S. and Diallo, S. (1999) Les parasitoses intestinales chez les habitants d'une zone péri-urbaine à nappe phréatique polluée par les nitrates d’origine fécale (Yeumbeul Sénégal). Cahiers Santé, 9, 351-356.

[14] Trape, J.F., Rogier, C., Konate, L., Diagne, N., Bouganali, H., Canque, B., Legros, F., Badji, A., Ndiaye, G., Ndiaye, P., Brahimi, K., Faye, O., Druilhe, P. and Da Silva, L.P. (1994) The Dielmo Project: A Longitudinal Study of Natural Malaria Infection and the Mechanism of Protection Immunity in a Community Living in a Holoendemic Area of Senegal. The American Journal of Tropical Medicine and Hygiene, 5, 
123-137. https://doi.org/10.4269/ajtmh.1994.51.123

[15] Fontenille, D., Lochouarn, L., Diatta, M., Sockhna, C., Dia, I., Diagne, N., Lemasson, J.F., Ba, K., Talla, A., Rogier, C. and Trape, J.F. (1997) Four Year's Entomological Study Transmission of Seasonal Malaria in Senegal and the Bionomics of Anopheles gambiae and Anopheles arabiensis. Transactions of the Royal Society of Tropical Medicine and Hygiene, 91, 647-652. https://doi.org/10.1016/S0035-9203(97)90506-X

[16] Larivière, M., Beauvais, B., Dercouin, F. and Traoré, F. (1987) Parasitologie Médicale. Ellipses, 238 p.

[17] Wiwanitkit, V., Waenlor, W. and Suyaphan, A. (2003) Contamination of Soil with Parasites in a Tropical Hilltribe Village in Northern Thailand. Tropical Doctor, 33, 180-182. https://doi.org/10.1177/004947550303300325

[18] Dossou-Yovo, L.R. (2000) Contribution à l'identification des sources de l'infestation humaine par les parasites intestinaux: Resultats obtenus avec la laitue cultivée dans la ville de Dakar (Sénégal). Mémoire de DEA Université Cheikh Anta Diop, 46 p.

[19] Chollom, S.C., Unata Iduh, M., Gyang, B.J., Abbah Idoko, M., Ujah, A., Ojonugwa Agada, G., Peter, J., Akele, Y.R. and Ameh Okwori, J. (2013) Parasitological Evaluation of Domestic Water Sources in a Rural Community in Nigeria. British Microbiology Research Journal, 3, 393-399. https://doi.org/10.9734/BMRJ/2013/3513

[20] Anyanwu Emeka, D., Lawrence Queen, O. and Onyele Onyinyechi, G. (2018) Parasitological Assessment of a Drinking Water Source in Umuahia, Southeast Nigeria. African Journal of Biology and Medical Research, 1, 55-62.

[21] Rafiei, A., Rahdar, M. and Valipour Nourozi, R. (2014) Isolation and Identification of Parasitic Protozoa in Sampled Water from the Southwest of Iran. Jundishapur Journal of Health Sciences, 6, 1-4. https://doi.org/10.5812/jjhs.23462

[22] Layla, B.A., Belhassen, K., Sabbahi, S., Karanis, P. and Nouiri, I. (2018) Assessment of the Parasitological Quality of Water Stored in Private Cisterns in Rural Areas of Tunisia. Journal of Water and Health, 16, 737-749. https://doi.org/10.2166/wh.2018.117

[23] OMS (1994) Directives de qualité de l'eau de boisson. Water and Sanitation, 1, 8-30.

[24] Nola, M., Njine, T., Monkedje, A., Foko, V.S., Djuikom, E. and Tailliez, R. (1998) Qualité bactériologique des eaux des sources et des puits de Yaoundé (Cameroun). Cahiers Santé, 8, 330-336.

[25] Chippaux, J.P., Houssier, S., Gross, P., Bouvier, C. and Brissaud, F. (2002) Etude de la pollution de l'eau souterraine de la ville de Niamey, Niger. Bulletin de la Société de Pathologie Exotique, 94, 119-123.

[26] Quick, R.E., Venczel, L.V., Gonzalez, O., Mintz, E.D., Highsmith, A.K., Espada, A., Damiani, E., Bean, N.H., De Hannover, E.H. and Tauxe, R.V. (1996) Narrow-Mouthed Water Storage Vessels and in Situ Chloration in a Bolivian Community: A Simple Method to Improve Drinking Water Quality. The American Journal of Tropical Medicine and Hygiene, 54, 511-516. https://doi.org/10.4269/ajtmh.1996.54.511

[27] Strauss, B., King, W., Ley, A. and Hoey, J.R. (2001) A Prospective Study of Rural Drinking Water Quality and Acute Gastrointestinal Illness. BMC Public Health, 1, 1471-1474. https://doi.org/10.1186/1471-2458-1-8

[28] Rufener, S., Mäusezahl, D., Mosler, H.J. and Weingartner, R. (2010) Quality of Drinking-Water at Source and Point-of Consumption Drinking Cup as a High Potential Recontamination Risk: A Field Study in Bolivia. Journal of Health, Population and Nutrition, 28, 34-41. https://doi.org/10.3329/jhpn.v28i1.4521 
[29] Yasin, M., Ketema, T. and Ketema, B. (2015) Physico-Chemical and Bacteriological Quality of Drinking Water of Different Sources, Jimma Zone, Southwest Ethiopia. BMC Research Notes, 8, 541. https://doi.org/10.1186/s13104-015-1376-5

[30] Parvez, A.K., Liza, S.M., Marzan, M., Ahmed, A. and Rahman, Md.S. (2016) Bacteriological Quality of Drinking Water Samples across Bangladesh. Archives of Clinical Microbiology, 7, 1-6. 